\title{
Enabling Factors and Effects of Corruption in the Defense Sector
}

\author{
Todor Tagarev *
}

\section{Introduction}

Corruption is a curse of modern societies, and the defense sector is just as susceptible to corruption as any other. As this essay will argue, a number of defense-specific factors, such as secrecy, urgency, and populist causes, facilitate corruption. Unchecked corruption impacts the operational effectiveness of the armed forces, the military's standing in society, the level of respect that international partners have for a given nation's military, the security of the citizens and, in its extreme manifestation, may threaten the democratic governance mechanisms and even the foundations of modern states. NATO has launched a "building integrity" initiative to address the problem of corruption in defense and in military operations that envisions systematic efforts to build integrity, increase transparency, and improve accountability of defense establishments. NATO currently pursues several practical activities that will be discussed in this essay, along with more detail on the compendium of best practices in building integrity and reducing corruption in defense.

\section{Corruption and Integrity in Defense}

Corruption hinders the development and undermines the security of modern societies and decreases trust in public institutions. The defense sector is not immune to the scourge of corruption. This may come as a surprise to many, given the high regard that the public generally has for the military around the world. According to the 2006 Transparency International/Gallup "Global Corruption Barometer" survey, the military - averaged globally - is one of the top three most respected institutions, and is almost as trusted in terms of corruption as NGOs and religious bodies. ${ }^{1}$ In many countries, the military is perceived as less corrupt than political parties, legislatures, business enterprises, and the media.

This high opinion of the incorruptibility of the military, however, varies strongly across countries and regions. For example, in Western Europe and the United States, the military is broadly perceived as being free of corruption. However, in the newly in-

Dr. Todor Tagarev was lead author and editor of Building Integrity and Reducing Corruption in Defense: A Compendium of Best Practices (Geneva: DCAF, 2010), http://www.dcaf.ch/ publications $/ \mathrm{kms} /$ details.cfm?lng=en\&id=113983\&nav1=5. Since September 2009, he has served as an advisor to the Minister of Defense of Bulgaria on strategic defense management issues.

1 Mark Pyman, Dominic Scott, Alan Waldron, and Inese Voika, "Building Integrity and Reducing Corruption Risk in Defense Establishments," Connections: The Quarterly Journal 7:2 (Summer 2008): 21-44. 
dependent states of Central and Eastern Europe, and in Africa and Latin America in particular, the military does not fare as well. ${ }^{2}$

Notwithstanding the high esteem in which the military is held in most societies, Transparency International's studies have rated defense among the most corrupt of the sectors that are entrusted with the management of public resources, along with extraction of oil and gas and construction industries. ${ }^{3}$ In the latest available study, defense fell to thirteenth on the list of industrial sectors where bribes to public officials are expected to be paid, and to eighth on the "State Capture" list. ${ }^{4}$

Hence, it has to be acknowledged that a generally high opinion of the military and the high potential for corruption in the defense sector coexist. This uneasy coexistence and the complex interaction of perceptions and behavioral patterns impact the design and the implementation of counter-corruption strategies and integrity-building programs.

In states where the military is a highly regarded institution, the defense establishment can inspire and lead wider institutional reform within a country. But it is also possible that, due to the lack of transparency and informed public debate on defense, a high regard for the military can hinder the implementation of integrity-building programs.

Needless to say, countering defense corruption in countries where the military is seen as corrupt is imperative. Often these are countries where corruption permeates many public and private sectors. In such cases, the example of the successful reform of defense institutions may have a considerable positive impact on other public institutions.

\section{Enabling Factors of Defense Corruption}

Corruption is the abuse of a position of trust for dishonest gain. Corruption within the defense sector may take many forms: kickbacks and bribes, the awarding of non-competitive contracts, or the manipulation of soldier payrolls. The recent and rapid growth of private military and security companies - performing activities previously within the realm of the state that are outsourced within the constraints of still rather limited regulations - has further increased opportunities for graft.

Below is a list of some of the rationales that facilitate corrupt practices in defense, namely "secrecy," "urgency" and "concern for the people." Although benign at first glance, the regular reference to these themes strongly limits the transparency of decision making and implementation, as well as the accountability of players in the defense sector, and thus creates a breeding ground for corruption.

Ibid., 31.
Ibid., 22.

4 Transparency International website, "Bribe Payers Index 2008 Table," available at www.transparency.org/policy_research/surveys_indices/bpi/bpi_2008\#bpi_table. The sectoral ranking evaluates the likelihood of companies from the nineteen sectors in the study to engage in "state capture," whereby parties attempt to wield undue influence over government rules, regulations, and decision making through private payments to public officials. 
- Secrecy is the first and worst enemy of transparency in defense. The prolific reference to secrecy in order to "protect national security interests" severely limits the opportunities for parliamentarian oversight and other forms of societal control of the executive branch. In defense procurement, for example, the reference to secrecy strongly limits the number of potential bidders, and can even lead to single-source procurement. That not only prevents competition but, as is too often the case, such schemes can also be deliberately designed and maintained in order to facilitate corrupt practices.

- The reference to urgency in meeting operational and other defense requirements allows for the implementation of simplified procedures or directly defying the rules (e.g., not holding open tenders and thus circumventing tender requirements for openness and competitiveness). A reference to urgency is often made in the defense establishments of new NATO members and Partner countries that contribute to international operations on an ad hoc basis or with "contingents" - i.e., units assembled for a single operational rotation. The need to meet urgent requirements, especially when combined with references to secrecy, creates an excellent ground for non-transparent and arbitrary decisions and, hence, for corruption.

- Populist slogans also often indicate corruption. One example is the call to "buy national" defense products and services, even when there are only a few or just a single national supplier of those products or services with questionable international competitiveness. Another example is the "concern for the soldiers' well-being" that has led to non-transparent exchanges of redundant military properties for housing for the military, non-transparent recreation contracts, etc. A third example is the call to act in the "public benefit," such as operating through offset arrangements that not only distort market mechanisms but also are conducive for paybacks in variety of ways.

This list is just a sample of the main "enemies" of transparency and accountability within the defense establishment. They are factors that also serve to increase the corruption potential of the defense sector, with abundant negative consequences.

\section{Effects of Corruption in Defense}

As was discussed above, uncurbed defense corruption poses considerable challenges to the efficiency of the defense establishment and the operational effectiveness of the armed forces. It can lower the public esteem for the military, negatively impact the security of a nation's citizens, diminish a military's international standing, and, in extreme cases, might pose a threat to the democratic process or the foundation of the state itself. These effects are examined below in five relatively distinct groups, each accompanied with an example taken from publicly available sources. 


\section{Diversion of Scarce Resources}

Corruption is costly. It diverts scarce resources from the appropriately priced generation of the defense capabilities a country needs and limits the opportunities to engage the armed forces in operations that enhance the security of the country and its allies. That means that the country is inefficient in implementing its security and defense policies and has lower levels of defense capabilities available to address security challenges and threats.

One of the many available examples clearly indicates the cost of corruption in terms of wasted money and lost opportunities for the technological modernization of defense. In an interview with Rossiiskaya Gazeta, Major-General Alexander Sorochkin, deputy chair of the Prosecutor's Office Investigations Committee, admitted that corruption in the Russian Armed Forces resulted in losses of 2.2 billion rubles (USD 78.6 million) to the state budget in the first nine months of 2008, and that the number of corruption-related crimes in the Russian Armed Forces increased by at least 30 percent compared to the same period in 2007 , to a total of 1,400 . The money lost is "enough to buy at least thirty modern T-90 main battle tanks," and flag officers have been involved in at least eighteen of the corruption cases. ${ }^{5}$

Russia's chief military prosecutor, Sergei Fridinsky, has added that, while the total number of crimes had declined in the country, offenses in the first nine months of 2008 soared 220 percent among the interior troops, 60 percent in the Emergencies Ministry, more than 10 percent in the border guard units of the Federal Security Service, and 24 percent in the Defense Ministry. Among these crimes, instances of bribe-taking and abuse of office increased by 50 percent, and over half of the offenses were related to military property and budget funds. ${ }^{6}$

And these numbers only account for corruption cases that have been brought to the attention of prosecution authorities. For this and other reasons, Russian President Dmitry Medvedev has made the fight against corruption one of his top priorities since coming to office in May 2008, signing a decree to set up a presidential anti-corruption council just two weeks after his inauguration.

From the perspective of society, defense corruption does not only hinder the effectiveness and solvency of the military; it also occurs at the expense of more socially productive investments, such as education, health care, innovation, and competitiveness.

\section{Limiting Operational Effectiveness}

When a country deploys its troops in operations, corruption dramatically impacts their operational effectiveness. Less than adequate capabilities limit the role and the usefulness of the military units. Equipment of lower quality puts the soldiers at higher risk,

5 "Military Corruption Costs Russia Almost $\$ 80$ million in 2008," RIA Novosti (2 December 2008); available at http://en.rian.ru/russia/20081202/118637765.html.

6 Ibid. 
and potentially increases casualties. By default, the morale of soldiers who are required to pay a bribe to get into an operation is low.

Corruption may be used, and in fact is used, by terrorists and organized criminal networks to acquire information, know-how, dangerous materials, and weapon technologies and systems. Corruption may further compromise operational security, as shown in the following example:

The corruption and ideological conversion of law enforcement officers by extremists in the North Caucasus has emerged as a major security threat, as the investigations of many major terrorist attacks have unearthed cases of corrupt or ideologically driven police officers who have assisted the attackers. Neither the boosting of passive defense measures nor increased preventive strikes against militant hideouts will succeed in curbing domestic terrorism if the Russian authorities fail to take serious action to root out the corruption that plagues the country's law enforcement community.

\section{Lower Morale and Regard for Defense Institutions}

Even occasional cases of corruption in defense put a stain on the entire defense establishment and, when left unchecked, may have a detrimental effect on public trust in the military and the ethos of the armed forces of the country. The pride that both the military and defense-sector civilian employees take in their service to the country is seriously degraded when they learn of corruption among their leadership. The lack of punishment in publicly known cases of drastic corruption among the high ranks of government further degrades the morale of the defense personnel and the public's opinion of the military. This in turn has a negative effect on the defense sector's ability to attract quality people to serve either in uniform or as civilian defense experts.

Endemic corruption can have detrimental effects on public trust in the defense establishment. In the example discussed below, public opinion sunk so low that the resulting cuts in the defense budget jeopardized even the nominal functioning of the defense establishment.

For years, there have been suspicions and media hints of large-scale corruption in the Bulgarian Defense Ministry and Armed Forces, but only a few cases of petty corruption have been officially acknowledged. Only after the change in government in 2009 did the Ministry of Defense and the law enforcement agencies begin to investigate the activities of the top leadership in the defense sector. Dozens of instances of corruption emerged, and by December 2009 Bulgarian prosecutors had charged a former defense minister with abuse of power in three cases. ${ }^{8}$

The official report for the first one hundred days of the new government acknowledged that the ministry and the armed forces are at the edge of a moral crisis, and

7 Simon Saradzhyan, "Dynamics of Maritime Terrorist Threats to Russia and the Government's Response," Connections: The Quarterly Journal 8:3 (Summer 2009): 53-84.

8 "Former Bulgarian Defence Minister Facing Contract Fraud Charges," Agence FrancePresse (20 November 2009); available at www.defensenews.com/story.php? $\mathrm{i}=4386991 \& \mathrm{c}=$ EUR. See also "The Defence Ministry in a Financial and Morale Collapse," Mediapool.bg (9 November 2009); available at www.mediapool.bg/show/?Storyid=158371. 
stated that in the practices of previous ministers, "the principles of integrity and good governance have been systematically thwarted, significant violations of the budgetary discipline have been allowed, ... unfavorable contracts have been signed, and numerous acts of corruption, irresponsibility, and waste have been tolerated." 9

While important for cleansing the defense establishment of practices of mismanagement, waste, and corruption, the disclosure of the scale and methods of corruption in defense increased resentment among the Bulgarian populace, and public trust in the defense establishment eroded further. One of the consequences was a severe cut in the defense budget, of a scale never witnessed before in the history of the country (see Figure 1). It is important to note that the global economic and financial crisis was only a minor motivation for this cut and, given the "morale collapse" of the defense institution, no defense experts, think tanks, or media outlets challenged this ruthless downsizing of the defense budget.

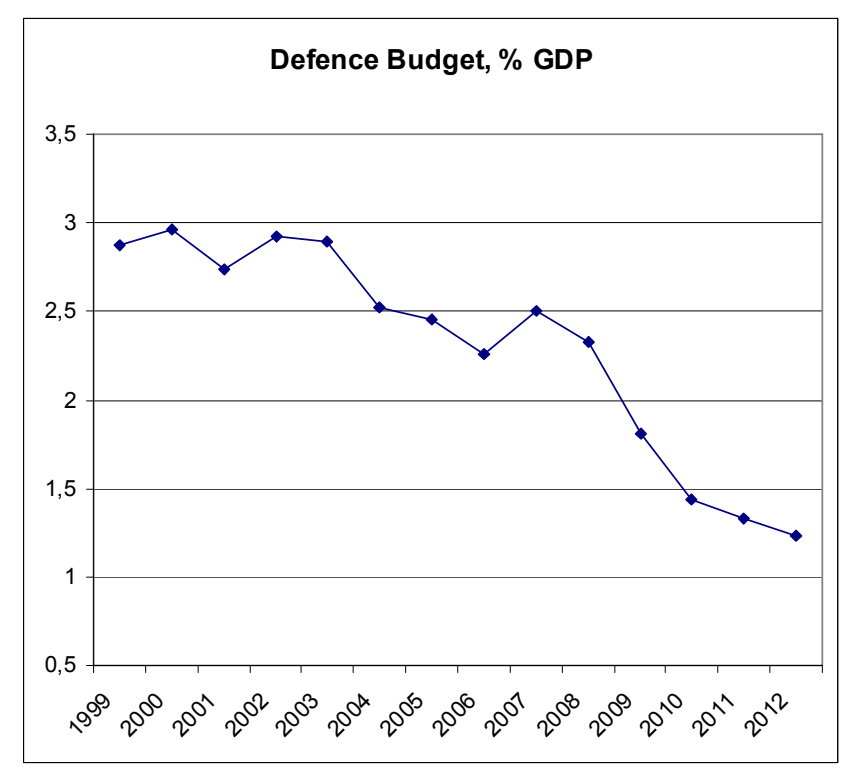

Figure 1: Bulgarian Defense Budget as a Percentage of GDP.

On the other hand, this severe cut jeopardized the sustainability of the Bulgarian military and the development of requisite capabilities, thus turning systemic corruption into a threat to national security and to Bulgaria's international standing as a reliable ally. Corruption-based limitations on capabilities and low morale, discussed in the pre-

9 Government of the European Development of Bulgaria, 100 Days Report (in Bulgarian), 73; available at www.government.bg/fce/001/0211/files/otchet100\%20days.pdf. 
vious section, reduce the credibility of national forces deployed on multinational peace missions. Overall, defense corruption has a negative impact on the prestige of the armed forces - and the country as a whole - in the eyes of allies, partners, and international organizations such as NATO, as well as in the wider international community.

\section{Immediate Security Threat}

Corruption-based links between security and defense organizations and organized criminal networks pose immediate threats to the security of the country and its citizens. Compromised defense and security sectors are conducive for the creation and functioning of organized crime and piracy groups. The quote on the situation in the North Caucasus above provides one example. The increasing frequency of piracy off the Somali coast provides another example of the link between security threats and corruption.

On 15 November 2008, Somali pirates hijacked the oil tanker Sirius Star, which was carrying twenty-five crewmen and 2.2 million barrels of oil. The ship was estimated to be worth approximately USD 150 million, with its cargo worth at least another USD 100 million. That incident, and a series of similar pirate attacks on smaller vessels, led to increased demands for an international naval presence in large areas of the Indian Ocean. There are many reasons for the recent increase of piracy off the Somali coast. One reason that is rarely referred to is the corruption linkage between pirates and Somalia's politico-military elites. According to Roger Middleton, consultant researcher at Chatham House, pirates are "paying off any significant political and military powers so they can carry on with their activities unhindered." 10

\section{Threat to the Foundations of the State}

The defense sector sometimes serves as a focus of corruption across government, and involves numerous actors. Given that the sector generally lacks the same level of transparency and accountability to the public and civil society that other sectors of the government do, it is relatively easy to divert money from the defense sector, and for behind-the-scenes networks to keep corrupt officials, businesses, intermediaries, accountants and lawyers, facilitated by spin doctors and fraudulent media, in business.

In such situations of "grand" corruption, oligarchic circles and shady businesses criminalize the entire economy and politics of the country and substitute their private interests for state policy - a phenomenon known in the specialized literature as "state capture." ${ }^{11}$ In this train of thought, countering corruption does not mean simply introducing regulations or "cleansing" the government; to defeat this form of corruption means to take the country back from the oligarchic circles of corrupt officials and

10 Barney Jopson, “Somalia's Bandits Broaden their Horizons," Financial Times (19 November 2008), 5.

11 See, for example, Joel S. Hellman, Geraint Jones, and Daniel Kaufmann, Seize the State, Seize the Day: State Capture, Corruption and Influence in Transition, World Bank Policy Research Working Paper No. 2444 (Washington, D.C.: The World Bank, September 2000). 
firms, eliminate customary practices of conducting illegal business, and to establish the rule of law, applied universally and in a transparent manner.

In a situation where the security or the very existence of a country is under threat either by external or internal enemies (or both), the situation is further aggravated by endemic corruption. The situation in Afghanistan highlights some of the ways in which corruption threatens the stability of a country.

The recently retired General Stanley McChrystal repeatedly highlighted corruption and weak state institutions as a major threat to the success of ISAF and Operation Enduring Freedom. He stated that insufficient comprehension of the dynamics of corruption and criminality led to a "crisis of confidence among Afghans." ${ }^{2}$ U.S. General Robert Cone, commander of the force that trains the Afghan army and police, has expressed similar sentiments, noting, "endemic corruption is one of the main obstacles to the Afghan army and police being able to take over their country's security duties." 13

Corruption and chronic mismanagement have been blamed for holding back reconstruction efforts in the country. International aid workers have said that up to one-third of the funding already dispersed (about USD 15 billion) has been wasted, which has deepened the resentment of locals toward foreign troops. A day after President Hamid Karzai was sworn in for a second term, the U.S. Secretary of Defense Robert Gates said, "Donors should tighten control of how the 'significant influx' of money into the country is used." ${ }^{14}$ Western leaders have put pressure on Mr. Karzai to deal with corruption and remove former warlords from government.

Fifteen current and former Afghan ministers are under investigation over allegations of corruption that have plagued the government of President Karzai. In his inaugural address for his second term as president, Karzai pledged to arrest those who spread corruption. International leaders - who have threatened to hold back troops and development aid unless Karzai cleans up corruption in his government-are watching closely to see if he keeps his promise. ${ }^{15}$

\section{Is Defense Corruption a Never-ending Story?}

Defeating defense corruption is a notoriously difficult endeavor, but it is a precondition for regaining societal confidence in the defense sector, as well as for providing defense and security at an affordable cost and with acceptable risk. And while it is far from clear whether defense corruption can be entirely overcome, there are proven ap-

12 "McChrystal: More Forces or 'Mission Failure'," Washington Post (21 September 2009); available at http://www.washingtonpost.com/wpdyn/content/article/2009/09/20/AR20090920 02920.html.

13 Jon Hemming, "Corruption Holds Back Afghan Army Expansion," Reuters (11 December 2008); available at www.reuters.com/article/idUSTRE4BA5S420081211.

14 "U.S. Secretary of Defence Robert Gates in the Pentagon," BBC News (21 November 2009).

15 A.J. Henninger, "Corruption: 15 Afghan Ministers under Investigation; Bribes, Perks, Skimming," on the DEFENSE (24 November 2009); available at http://onthedefense.wordpress.com/ 2009/11/24/corruption-15-afghan-ministers-under-investigation-bribes-perks-skimming. 
proaches and good practices that, when implemented in the proper context, can be used to curb corruption.

The section below describes the current approach undertaken by NATO and the Euro-Atlantic Partnership Council in tackling the challenge of defense corruption. It builds on the contribution of various players, including non-governmental think tanks and activist groups. For example, a non-governmental study conducted in 2008 identified several key measures that would lead to a quick reduction of the corruption potential in the Bulgarian defense establishment: ${ }^{16}$

- Creation of favorable normative and procedural conditions for the eradication of corruption in defense, with a priority on:

o Elaboration and steady application of objective-oriented budgeting, based on programs

o Substantial increase in the transparency of the procurement process and admission of a maximum number of bidders in tender procedures

o Immediate discharging of the Ministry of Defense and the military from all types of economic functions

o Suspension of property exchanges and similar transactions

o Sending only existing units with already developed capabilities to participate in operations abroad

- Conducting additional studies on problems connected with corruption in stabilization and reconstruction operations; formulating and realizing offset and similar programs and projects; identifying the roots of non-efficient management; conducting development and comparative analysis of methods and approaches for solving those issues

- Monitoring the level of corruption potential in the defense sector, of the measures undertaken by the legislative and executive power, business and nongovernmental organizations to counter corruption, and of the real level of corruption.

In this example, while admitting that the treatment of defense corruption risks and the creation of counter-corruption strategies and measures has to be comprehensive, the application of integrity-building programs is always context-specific and requires the establishment of clear priorities and realism in matching objectives and human and organizational resources.

16 Todor Tagarev, "Defence Decision-making and Corruption Risks," in Integrity in Defence: Effective, Transparent and Accountable Management, ed. Avgustina Tzvetkova (Sofia: Euro-Atlantic Education Initiative, 2009), 189-214. 


\section{NATO's Building Integrity Initiative}

The issue of corruption already featured prominently in the declaration of the 2006 NATO Summit in Riga ${ }^{17}$ and the related discussions on inviting new countries to join the Membership Action Plan. ${ }^{18}$ The NATO Summit in Bucharest in 2008 gave "priority to several new practical initiatives, which include building integrity in defense institutions...."19 One of the practical measures was the establishment of a NATO "Integrity Building Trust Fund," with Poland, Switzerland, and the United Kingdom as lead nations. ${ }^{20}$ This trust fund facilitated the launch of the first three practical initiatives:

- A five-day integrity-building course, led by the United Kingdom. By mid2009, this course had been conducted in the U.K. Defence Academy in Shrivenham, the NATO School in Oberammergau, the Peace Support Operations Training Centre in Sarajevo, and the National Defense Academy of Ukraine in Kiev. Representatives of more than twenty nations have participated in the course.

- Creation and validation of an "Integrity Self-Assessment Process" for defense and security, resulting from collaboration between NATO nations and Transparency International, led by Poland. ${ }^{21}$

- A compendium of best practices in building integrity and reducing corruption risks in defense. This Swiss-led initiative was implemented by an international network of security and defense experts and is managed by the Geneva Centre for the Democratic Control of Armed Forces (DCAF). ${ }^{22}$

In February 2009, NATO-in cooperation with the Naval Postgraduate School, which is the Partnership for Peace Training and Education Center in North America, and Transparency International - conducted a conference in order to evaluate the progress that had been made in developing practical tools. The conference took place in Monterey, California and was used to exchange views and experiences in implement-

17 NATO, "Riga Summit Declaration," NATO Press Releases (2006)150 (29 November 2006); available at www.nato.int/docu/pr/2006/p06-150e.htm.

18 See, for example, Taras Kuzio, "Georgia Outshines Ukraine at Recent NATO Summit in Riga," Kiev Post (20 December 2006); available at www.gmfus.org/publications/article.cfm? id=255\&parent_type $=$ P.

19 NATO, "Bucharest Summit Declaration," para. 32 (3 April 2008); available at www.nato.int/ cps/en/natolive/official_texts_8443.htm.

20 "Trust Fund Contributes to Good Governance," NATO News (1 July 2008); available at www.nato.int/cps/en/natolive/news_8077.htm.

21 Mark Pyman, Building Integrity and Reducing Corruption Risk in Defence Establishments: Ten Practical Reforms, with foreword by Lord George Robertson of Port Ellen (London: Transparency International, April 2009).

22 The compendium is described in the next section. 
ing counter-corruption and integrity-building strategies as part of broader defense institution building programs. ${ }^{23}$

At the sixtieth anniversary NATO Summit in Strasbourg/Kehl in 2009, NATO's heads of state and government reiterated the Alliance's commitment to counter corruption, and encouraged the EAPC "to further develop the Building Integrity initiative which promotes transparency and accountability in the defence sector, and to report back to us on this initiative at our next Summit."24

\section{A Compendium of Best Practices}

The Geneva Centre for the Democratic Control of Armed Forces (DCAF) published the Compendium in the beginning of $2010 .{ }^{25}$ It includes contributions from twenty-five authors from twelve nations, structured in four parts. Part I of the compendium presents national and international experiences in building democratic and effective defense institutions and countering corruption in defense. It presents the foundations of a strategic approach to reduce corruption risks in defense. The approach combines efforts to build integrity, increase transparency, and improve accountability. Such a combination increases the moral burden of corrupt behavior, reduces perceived rewards, and increases the expected costs, or punishment.

Part II includes nine chapters that look in detail at the sources of and reasons for corruption in defense. The majority of chapters examine corrupt behavior, as well as best practices in building integrity and enhancing transparency and accountability in the primary defense management areas:

- Personnel policies and manpower management

- Defense budgeting and financial management

- Procurement

- Offset arrangements

- Outsourcing

- Privatization

- Public-private partnerships in defense

- Utilization of surplus equipment and infrastructure

- The involvement of defense personnel and assets in economic activities.

23 Report on the Building Integrity and Defense Institution Building conference, held in Monterey, CA, 25-27 February 2009.

24 NATO, "Strasbourg/Kehl Summit Declaration," para. 36 (4 April 2009), Press Release PR/CP (2009)044; available at www.nato.int/cps/en/natolive/news_52837.htm?mode= pressrelease.

25 Todor Tagarev, ed., Building Integrity and Reducing Corruption in Defence: A Compendium of Best Practices (Geneva: DCAF, 2010). 
One chapter focuses on corruption risks and integrity issues related to contemporary military operations, while the final chapter in Part II examines defense-related corruption in countries with unresolved territorial disputes.

Part III then presents details on the relevant regulatory frameworks and proven practical approaches to integrity building at the level of the individual, the executive branch of government (and the defense ministry in particular), parliaments and audit offices, ombudsman institutions, the defense industry, civil society and the media, and international organizations.

The practicalities of designing and implementing integrity-building programs in the defense sector are discussed in Part IV of the compendium. Of particular importance in this regard is to acknowledge the specific culture of the defense organization in a particular country, and to strengthen those features of the organizational culture that contribute to individual and organizational integrity and deter corrupt behavior. These good practices can then be disseminated to other public organizations in the country.

Three annexes present resources-official documents, guides and handbooks, methodologies, databases accessible online, selected monographs and reports - as well as the defense-related work of Transparency International, and the abbreviations most often used in counter-corruption sources.

\section{Conclusion}

Although the defense sector employs some of the most highly respected individuals in many societies, it is not free from corruption. Corruption comes in many forms and disguises, and its scale increases when the defense sector is not sufficiently transparent and accountable to parliaments and society. The increase of transparency may lead to the exposure of corrupt activities, which can have a damaging impact in the short term, but in the long term it is a powerful tool for freeing the defense sector from the vices of corruption. There are many examples of corruption in defense, but there are also established practices that can help minimize corruption risks through a combination of legislative, organizational, and procedural measures, along with efforts directed at individual behavior and organizational culture. And while there is hardly a country or a defense organization that is entirely free from corrupt acts, systemic efforts at building integrity, increasing transparency, and improving accountability of the defense sector minimize corruption risks and maximize the efficiency of the armed forces and their standing in their society.

With this understanding in mind, NATO and its partners launched the Building Integrity Initiative. Situated in the context of defense institution building, it involves governments along with international and non-governmental organizations. It is expected that it will lead to increased effectiveness and efficiency of the militaries of NATO members and partners and of NATO operations, thus having a direct impact on Euro-Atlantic stability and security. 


\section{Bibliography}

Bribe Payers Index 2008 Table. Transparency International website, 2008.

Bucharest Summit Declaration. Bucharest, Romania: NATO, 2008.

Building Integrity and Defense Institution Building. Monterey, CA, 2009.

Former Bulgarian Defence Minister Facing Contract Fraud Charges. Agence FrancePresse, 2009.

Hellman, Joel S., Geraint Jones, and Daniel Kaufmann. Seize the State, Seize the Day: State Capture, Corruption and Influence in Transition . World Bank Policy Research Working Paper No. 2444 , 2000.

Hemming, Jon. Corruption Holds Back Afghan Army Expansion. Reuters, 2008.

Henninger, A.J.. Corruption: 15 Afghan Ministers under Investigation; Bribes, Perks, Skimming., 2009.

Jopson, Barney. "Somalia’s Bandits Broaden their Horizons." Financial Times (2008): 5.

Kuzio, Taras. "Georgia Outshines Ukraine at Recent NATO Summit in Riga." Kiev Post (2006).

McChrystal: More Forces or 'Mission Failure'. Washington Post (2009).

Military Corruption Costs Russia Almost $\$ 80$ million in 2008. RIA Novosti, 2008.

Pyman, Mark. Building Integrity and Reducing Corruption Risk in Defence Establishments: Ten Practical Reforms. London: Transparency International, 2009.

Riga Summit Declaration. NATO, 2006.

Saradzhyan, Simon. "Dynamics of Maritime Terrorist Threats to Russia and the Government's Response." Connections: The Quarterly Journal 8, no. 3 (2009): 53-84.

Scott, Dominic, Mark Pyman, Inese Voika, and Alan Waldron. "Building Integrity and Reducing Corruption Risk in Defense Establishments." Connections: The Quarterly Journal 7 (2008): 21-44.

Strasbourg/Kehl Summit Declaration. Strasbourg/Kehl: NATO, 2009.

Tagarev, Todor. "Defence Decision-making and Corruption Risks." In Integrity in Defence: Effective, Transparent and Accountable Management, 189-214. Sofia: EuroAtlantic Education Initiative, 2009.

Tagarev, Todor. Building Integrity and Reducing Corruption in Defence: A Compendium of Best Practices, Edited by Todor Tagarev, Philipp Fluri, Adrian Kendry, Mark Pyman, Simon Lunn and Ashley Thornton. Geneva Centre for the Democratic Control of Armed Forces, 2010.

The Defence Ministry in a Financial and Morale Collapse. Mediapool.bg, 2009.

Trust Fund Contributes to Good Governance. NATO News, 2008.

U.S. Secretary of Defence Robert Gates in the Pentagon. BBC News, 2009. 